\title{
Life History Traits and Invasion Success of Parthenium hysterophorus L. in Kathmandu Valley, Nepal
}

\author{
Seerjana Maharjan' ${ }^{1}$, Srijana Joshi ${ }^{2}$, Bharat Babu Shrestha ${ }^{3 *}$, Anjana Devkota ${ }^{3}$ and Pramod \\ Kumar Jha ${ }^{3}$ \\ ${ }^{I}$ Natural Products Research Laboratory, Department of Plant Resources, Kathmandu, Nepal \\ ${ }^{2}$ International Center for Integrated Mountain Development (ICIMOD), Lalitpur, Nepal \\ ${ }^{3}$ Central Department of Botany, Tribhuvan University, Kathmandu, Nepal \\ e-mail: shresthabb@gmail.com
}

\begin{abstract}
Parthenium (Parthenium hysterophorus L.) is an invasive alien species of global significance which is rapidly expanding in Nepal and other Asian countries with negative impacts on species diversity, health of human and livestock, and productivity of pasture and agriculture. To understand the invasive success of this weed, we analysed soil of its invaded sites, morphological traits, biomass allocation, leaf attributes, and phenology in the Kathmandu valley. The roadside soil, which is loamy sand in the valley is highly suitable for the growth and proliferation of the parthenium weed where its density has become double in less than a decade. An average size plant was $112 \mathrm{~cm}$ tall with $12 \mathrm{~cm}$ long tap root and produced 2637 achene per plant (max. 3865 per plant). A combination of different leaf traits enables the parthenium to grow under diverse habitats such as resouces poor condition (due to low specific leaf area, SLA), disturbed habitats (due to low leaf dry matter content, LDMC) as well as productive sites (due to high leaf nitrogen content). During rainy season it completes lifecycle in 16-18 weeks. Relatively long (12-16 weeks) reproductive period with high output of small seeds and their capacity to germinate and flower anytime in the year make parthenium a successful invasive weed in the Kathmandu valley.
\end{abstract}

Key words: biomass allocation, germination, leaf dry matter content, phenology, specific leaf area, seed output

\section{Introduction}

Parthenium (Parthenium hysterophorus L., Family Asteraceae), also known as false ragweed, Santa Maria, carrot grass or feverfew, is among the most troublesome invasive alien species of the world. The weed is a native of Central America and has invaded Asia, Australia and Africa (Dhileepan 2009). Absence of natural enemies, wide adaptability to varying soil and micro-environment, high fecundity, efficient seed dispersal mechanisms, and allelopathic impact on most other plants have enabled parthenium to invade a variety of habitats in its invasive range particularly under the situation of human activities (Navie et al. 1996). It causes health hazards to man and animals leading to socio-psycho-economic problem (Kololgi et al. 1997), modifies soil and species composition of native vegetation (Chippendale \& Panetta 1994, Nigatu et al. 2010, Timsina et al. 2011), and reduces agriculture productivity (Tamado et al. 2002). Ecological damage and economic losses due to invasion by parthenium in the countries like India and Australia has been substantial (Evans 1997). In Queensland (Australia) alone, the potential economic loss in beef industry due to parthenium was estimated to be AUS \$ 109 per annum during 1990s (Adamson 1996).

In Nepal, the parthenium was first reported in 1967 (Tiwari et al. 2005) but the major population outburst has occurred since 1990s. Currently, the weed has already invaded Tarai, Siwalik (particularly the dun valleys) and mid hill regions of Nepal (BB Shrestha, unpublished data). From southern part of the country, 
the weed is spreading to northward along road networks. Since the first report of the weed by Mishra (1990) from Kathmandu valley, it has been rapidly spreading and currently it can be found in most parts of the valley (Shrestha et al. 2011) with potential negative impact on ecosystem and public health. The major objective of this study was to understand the life history traits and invasive success of this weed in Kathmand valley.

\section{Methodology}

\section{Study area}

The Kathmandu valley $\left(85^{\circ} 10^{\prime}\right.$ to $85^{\circ} 32^{\prime} \mathrm{E}, 27^{\circ} 28^{\prime}$ to $27^{\circ} 34^{\prime} \mathrm{N}$, elevation 1350 to $1500 \mathrm{~m}$ above sea level (m asl)) is roughly elliptical in outline, with its east-west length about $25 \mathrm{~km}$, maximum north-south width 19 $\mathrm{km}$, and area approximately $339 \mathrm{~km}^{2}$. The valley is surrounded by high mountains such as Shivapuri (2732 $\mathrm{m}$ asl), Nagarjun (2188 m asl), Chandragiri (2482 m asl) and Phulchoki (2715 $\mathrm{m}$ asl). The valley is traversed by two main rivers, Bagmati and Vishnumati. The climate is warm temperate, but influenced by the tropical monsoon with wet summer and dry winter. Maximum and minimum temperature ranges from 30 to $33^{\circ} \mathrm{C}$ in summer and -3 to $0^{\circ} \mathrm{C}$ in winter, respectively. The temperature and rainfall recorded at airport in 2004 has been presented in the Fig. 1. Soil of Kathmandu valley is of recent origin and is azonal, i.e. with no distinct soil profile (Bhatt 1977). In most parts, it is clayey with a lot of organic matter. Soil types in the valley vary from silty loam to clayey loam.

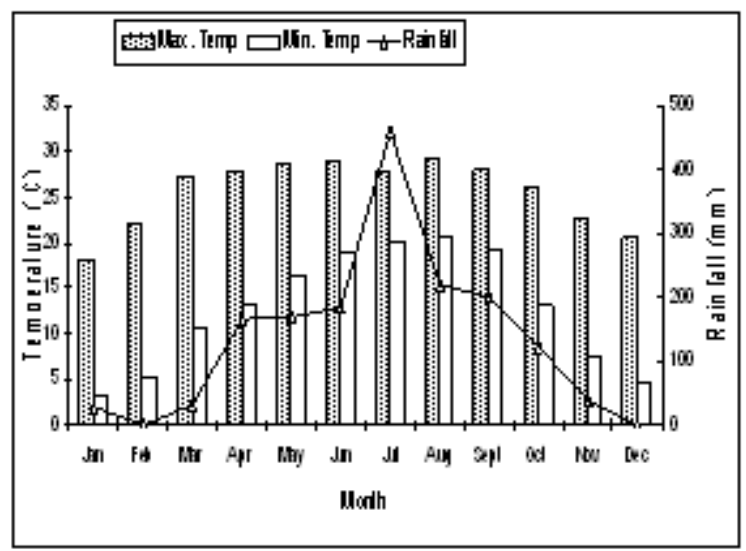

Fig. 1. Average monthly temperature and rainfall at Tribhuvan International Airport weather station $\left(27^{\circ} 42^{\prime} \mathrm{N}, 85^{\circ} 22^{\prime} \mathrm{E}, 1336 \mathrm{~m}\right.$ asl), Kathmandu in 2004 (Source: Department of Hydrology and Meteorology/HMGN).
Kathmandu being a capital city of Nepal is witnessing rapid urbanization in recent decades. Agricutlural land has been changed into new residential areas. Therefore, vegetation is mainly limited to the roadside and fallow land. The roadside vegetation has been rapidly invaded by invasive alien species such as parthenium weed, crofton weed (Ageratina adenophora (L.) King \& Robinson), lantana (Lantana camara L.), alligator weed (Alternanthera philoxeroides (Mart.) Griseb.), rough cockle bur (Xanthium strumarium L.), etc. Among them, parthenium has been spreading at alarmingly high rate and can be found in most parts of the Kathmandu valley (Shrestha et al. 2011). We selected eight sites (Chovar, Kirtipur, Balkhu, Hattiban, Nakkhu, Sitapaila, Chabahil and Tilganga) in the valley for the study of soil characteristics, parthenium density, and it's morphological characters (Fig. 2). Due to logistic problems and disturbances, phenology of this plant was monitored only at Chobhar and Kirtipur with two additional sites Balaju and Gauchar (airport area). These sites are located between 1290 and $1340 \mathrm{~m}$ above sea level ( $\mathrm{m}$ asl). In all sites, parthenium weed was the most dominant plant species. The data were collected during 2003-2004.

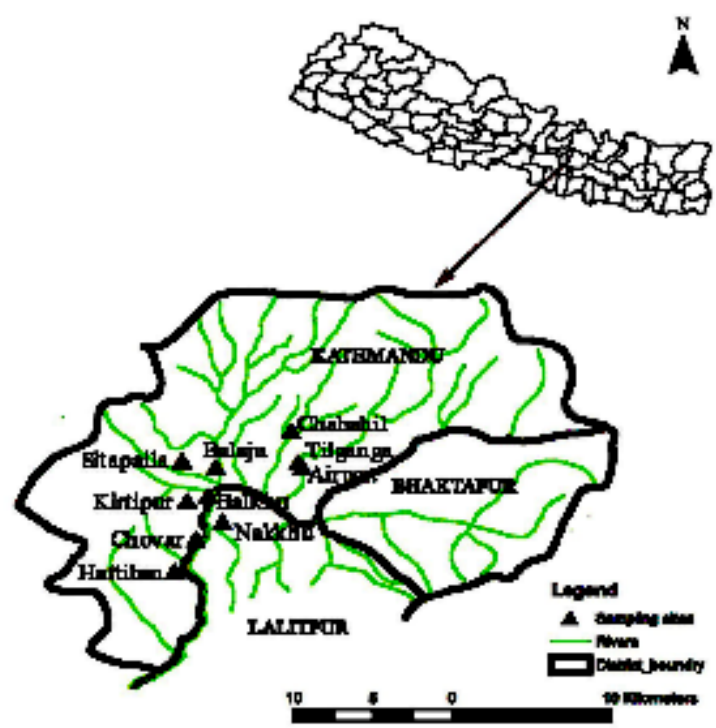

Fig. 2. Map of Kathmandu valley showing the sampling sites.

\section{Field sampling and laboratory analyses Parthenium density}

Density $\left(\mathrm{stem} / \mathrm{m}^{2}\right.$ ) of parthenium was determined by quadrat method. At each of the eight sites, ten square quadrats $(2 \mathrm{~m} \times 2 \mathrm{~m})$ were sampled and the number of individual plants were counted. 
Seerjana Maharjan et al./Life History Traits and Invasion .........

\section{Soil}

Soil samples were collected from four corners and middle of each quadrat at $15 \mathrm{~cm}$ depth. All the collected samples of each site were mixed thoroughly after removal of litters and other foreign materials. Thus, there were eight composite samples in total, one from each site. In the laboratory each sample was divided into three parts and analyzed separately for their physical and chemical characters. Before analysis, the soil samples were air-dried in shade for a week. Soil physical properties (texture and water holding capacity) were determined following Zobel et al. (1987) at the Central Department of Botany, Tribhuvan University, Kirtipur. Soil pH (Fischor's digital meter), soil organic matter (Walkey and Black's method), total nitrogen (micro-Kjeldahl method), available phosphorus (Olsen's method) and available potassium (atomic absorption spectrophotometer method) were determined at the Soil Analysis and Service Centre, Hariharbhavan, Lalitpur. Method of soil chemical analyses used in this work have been described in Gupta (2000).

\section{Morphological traits and biomass allocation}

For measuring morphological traits and biomass allocation, ten individual plants of parthenium were completely uprooted from each of the eight sites (where density of it was measured) in August 2003. The selected plants were fully grown with flowers and fruits. Length of tap root and main shoot of each plant were measured. The number of leaves (live as well as dead) attached to the plant, and branches and flower heads present in the sample plant were counted. Seed out put of each plant was obtained as the product of the number of flower head and the number of achene (i.e. 5) per flower head. The vegetative (root, stem and leaf) and reproductive parts (inflorescence/flower head) of each collected plant were separated and oven dried at $80^{\circ} \mathrm{C}$ for 24 hrs to determine the dry mass. Reproductive allocation (RA) is the dry mass of flower head expressed as percentage of total biomass while the vegetative allocation (VA) is the sum of dry mass of root, stem and leaf expressed as the percentage of total biomass. Root to shoot ratio of biomass and the total biomass per plant were also calculated.

\section{Leaf attributes}

1. Stomatal features: Stomatal size, frequency and index were determined in epidermal peelings of fully expanded leaves collected freshly at around 12 o'clock from Kirtipur. Epidermal peelings of lower and upper surfaces of the fresh leaves were taken out with the help of a forcep and mounted in glycerine (10\%). It was observed under precalibrated microscope (fitted with ocular micrometer) under $45 \times 10$ magnification. Length and breadth of guard cells of three stomata were measured in each peeling. The number of stomata and epidermal cells were counted in five microscopic fields for both upper and lower surface of the leaf. Stomatal frequency (number/ $\mathrm{mm}^{2}$ ) and stomatal index (\%) [(number of stomata $\times 100) /($ number of epidermal cells + number of stomata)] were calculated following Metecalfe and Chalk (1965).

2. Specific leaf area (SLA) and leaf dry matter content (LDMC): Forty fully expanded, healthy and non-senescent leaves were collected from 15 plants found in vegetative stage at Kirtipur. Immediately after collection, the leaves were placed between damp blotting papers, resealed in plastic bags and maintained in dark overnight. Then the leaves were blotted dry with blotting paper to remove surface water and immediately weighed to get saturated mass of the leaves. Leaf area was determined with the help of graph paper following the method described in Zobel et al. (1987). They were then oven dried at $70^{\circ} \mathrm{C}$ for $48 \mathrm{~h}$ and weighed to get dry mass. SLA and LDMC were calculated using the following formulae: SLA $\left(\mathrm{m}^{2} / \mathrm{kg}\right)=$ projected leaf area/leaf dry mass; LDMC $(\mathrm{mg} / \mathrm{g})=$ leaf dry mass/leaf saturation mass.

3. Leaf nitrogen $(\mathbf{N})$ : Fifteen leaves from three individuals were collected and air dried for a week. Such ten samples were taken each from Kirtipur and Gauchar sites, separately. For determining moisture content, sub-samples $(1 \mathrm{~g})$ were oven dried at $70^{\circ} \mathrm{C}$ for $48 \mathrm{~h}$. Leaf $\mathrm{N}$ content was determined by modified micro Kjeldahl method following the procedure described by Horneck and Miller (1998).

\section{Pollen viability}

Five freshly opened flower heads were collected from two healthy looking individuals from each of the three localities (Balaju, Kirtipur and Gauchar). Pollen grains from all 15 flower heads were dusted on a glass slide with the help of a needle and a drop of 
Muntzing solution (acetocarmine and glycerine, 1:1) was added. It was then covered with a cover slip without squash. After thirty minutes, the prepared slides were observed under a microscope. The number of viable and total pollens were counted in five microscopic fields. Those pollen grains that were clearly swollen (spherical) and red, presenting homogenous cytoplasm were considered as viable ones and those pollen grains that were wrinkled (deformed) and not stained well were considered as non-viable ones (Sakya 2001). A total of 1111 pollen grains were counted in five microscopic fields in total and the pollen viability was calculated as the percentage of total pollens counted.

\section{Achene mass}

Freshly collected achenes (cypsela with lateral sterile florets) were air dried in shade for a few days and packed in airtight plastic bags. After one month, three batches of achenes, each containing 100, were weighed to determine mass.

\section{Germination}

Achenes were collected during September 2003 from Balkhu site and were stored at cool and dark place. Germination test was done in May 2004 under ambient laboratory condition. The achenes were soaked in water for about 10 minutes and were sterilized by sodium hypochlorite solution (1\%). Ten healthy achenes were placed in each of the five plastic Petri dishes, with number of seeds totalling to 50. The Petri dish was sterilized by absolute alcohol with a layer of filter paper soaked in $5 \mathrm{~mL}$ distilled water. In every 72 hours, $10 \mathrm{~mL}$ distilled water was added in each Petri dish. Germination was observed daily.

\section{Phenological study}

Ten juvenile parthenium plants with equal height were tagged at four sites (Chobhar, Balaju, Kirtipur and Gauchar) in May 2004. To estimate average age of the tagged individuals, seeds collected from these sites were germinated separately in earthen pots filled with soil from the respective sites. The number of days required to attain the height of tagged individuals was recorded. The tagged individuals were examined once in every two weeks in general and once a week during the phenologically active period (last of July to August). Field observations continued till October 2004, when fruit fall completed in the tagged plants. Phenological events recorded were: germination, vegetative stage, flowering, fruiting, seed development and senescence. For close observation of some other phenological events like anthesis, anther dehiscence, fruit development and seed formation, plants were grown in earthen pots near the laboratory. The data obtained from field observations from all sites were summarized to obtain the percentage of plant population in germination, vegetative, flowering, fruiting, seed formation and senescence stage [e.g. flowering $(\%)=$ number of individuals in flowering stage $\times 100$ / total number of the individuals in all stages].

\section{Results and Discussion}

\section{Soil}

The soil of parthenium invaded sites was mostly loamy sand with water holding capacity ranging from 17 to 63 $\%$ (mean 47\%) (Table 1). The soil was acidic to neutral and organic matter was low to moderate $(1.13-4.12 \%)$. Soil nitrogen ranged from 0.05 to $0.206 \%$, available phosphorus from 32 to $70 \mathrm{~kg} / \mathrm{ha}$, and available potassium from 75 to $745 \mathrm{~kg} / \mathrm{ha}$. Naturally the soil of Kathmandu valley is mostly clayey and varies from silt loam to clayey loam (Bhatt 1977). But high proportion of sand in soil of the present study sites and relatively low nutrient content might be due to the deposition of construction materials (e.g. sand, gravels) along the roadside where parthenium weed was the most common. This kind of loamy sand soil is more suitable for the growth and reproduction of parthenium weed than the clay soil (Annapurna \& Singh 2003). This weed can establish successfully in the nutrient poor soil too where there is frequent disturbance to native vegetation (Navie et al. 1996). Therefore, the roadside habitat of the Kathmandu valley appears to be suitable for the rapid growth and colonization of this plant.

Table 1. Soil characteristics of the sites invaded by parthenium

\begin{tabular}{l|c|c}
\hline Parameters & $\begin{array}{c}\text { Range of } \\
\text { value }\end{array}$ & Mean(tSD) \\
\hline pH & 5.47 .4 & $6.34 \pm 0.65$ \\
Water holding capacity (\%) & $17-63$ & $47 \pm 18$ \\
$\quad$ Sand (\%) & $52-97$ & $73 \pm 14$ \\
Soil texture Silt (\%) & $2-26$ & $21 \pm 12$ \\
$\quad$ Clay(\%) & $0.23-10.91$ & $5.33 \pm 3.73$ \\
Orgaric matter (\%) & $1.13-4.12$ & $2.58 \pm 0.87$ \\
Total ritrogen (\%) & $0.055-0.206$ & $0.124 \pm 0.042$ \\
Available phos phoms & $32-70$ & $59 \pm 13$ \\
(kg/ha) & & \\
Available potassium & $75-745$ & $255 \pm 222$ \\
(kg/ha) & & \\
\hline
\end{tabular}




\section{Density}

The mean density of parthenium weed in Kathmandu valley, which was sampled in 2003 , was $20 \mathrm{stem} / \mathrm{m}^{2}$ (Table 2). At Kirtipur site, the density was $26 \mathrm{stem} / \mathrm{m}^{2}$ (data not shown). Near the same site in a roadside fallow land, the density of this weed reached to 52 $\mathrm{stem} / \mathrm{m}^{2}$ in 2011 (Pokhrel 2012). When various land use types (e.g. roadside fallow land, tree plantation, abandoned agricultural land) were sampled in Kirtipur municipality area in 2011 , the mean density of parthenium weed was $40 \mathrm{stem} / \mathrm{m}^{2}$ (KC 2013). These data showed that density of parthenium weed has been increasing in the Kathmandu valley and it had doubled in less than a decade. This is also evident by the very high density $\left(298 \mathrm{stem} / \mathrm{m}^{2}\right)$ of this weed in a grassland of Hetaunda, Makawanpur (Karki 2009) which had longer invasion history than of the Kathmandu valley.

Table 2. Density, vegetative and reproductive characters of parthenium in Kathmandu valley

\begin{tabular}{|c|c|c|}
\hline Attributes & Range of vahue & $\operatorname{Mean}( \pm \mathrm{SD})$ \\
\hline Density (ste m/ $\left.\mathrm{m}^{\prime}\right)$ & $11-47$ & $20 \pm 11.92$ \\
\hline Root length (cm) & $11-15$ & $12 \pm 1.43$ \\
\hline Stem length (cm) & $100-132$ & $112 \pm 11.12$ \\
\hline No. of leaves per plant & $16-23$ & $20 \pm 2.43$ \\
\hline No. of flower heads per plant & $297-773$ & $527 \pm 145.6$ \\
\hline Seed output per plant & $1392-3864$ & $2637 \pm 727$ \\
\hline Achene mass ( $g / 100$ achene) & - & 0.05 \\
\hline Seed germination $(\%)$ & - & 82 \\
\hline
\end{tabular}

\section{Morphological traits and biomass allocation}

The mean length of root and stem were 12 and $112 \mathrm{~cm}$, respectively (Table 2). The number of flower heads in plants varied from 297 to 773 , and the mean seed output per plant was 2637 with maximum record of 3865. Annapurna and Singh (2003) reported seed output from 330 (clay soil) to 9425 (loamy sand) and showed that it varied with soil texture. In a soil which is comparable to the present study area, they reported seed output to be 9425 which is more than two times the present value. This disparity in data could be due to different growth condition. In the present study the plants were harvested from naturally growing stands with a mean density $20 \mathrm{stem} / \mathrm{m}^{2}$ but the plants examined by the above researchers were grown individually in earthen pots. Both interspecific and intraspecific competition could have reduced branching and thus the seed output but in the study conducted by them, parthenium plants were grown alone in competition free environment. The reduced branching in plants naturally growing in dense stands is also evident by the lower value (0.24) of root to shoot ratio (Table 3) than in pot-grown plants in similar soil condition (0.18 in loamy sand, Annapurna \& Singh 2003).

Table 3. Biomass allocation in parthenium weed growing naturally in Kathmandu valley

\begin{tabular}{l|c|c}
\hline Attributes & Range of value & Mean (tSD) \\
\hline Root (g/plant) & $2.53-7.87$ & $4.01 \pm 1.74$ \\
Stem (g/plant) & $5.77-17.76$ & $12.32 \pm 3.71$ \\
Leaf (g/plant) & $1.42-5.81$ & $3.51 \pm 1.80$ \\
Flower heads (g/plant) & $0.73-2.15$ & $1.37 \pm 0.53$ \\
Root to shoot ratio & 0.140 .39 & $0.24 \pm 0.77$ \\
Total dry mass (g/plant) & $11.38-29.70$ & $21.2 \pm 6.54$ \\
Allocation to vegetative parts $(\%)$ & $92-95$ & $93 \pm 1$ \\
Allocation to re productive parts $(\%)$ & $5-8$ & $7 \pm 1$ \\
\hline
\end{tabular}

\section{Leaf attributes}

The leaf of parthenium weed was amphistomatic i.e. having stomata on both the surfaces; and the stomata were Ranunculaceous or anomocytic type, in which the stoma remains surrounded by a limited number
(5-6 in this case) of subsidiary cells which are quite alike the remaining epidermal cells. The size of stomatal apertures (guard cell and pore) was $0.018 \mathrm{~mm} \times 0.015$ $\mathrm{mm}$. Stomatal frequency and index were higher on lower 
surface than on the upper surface of leaf which is a common feature of most terrestrial plants (Meidner \&
Mansfield 1968). The stomatal frequency and index were higher on lower leaf surface than on upper (Table 4).

Table 4. Leaf attributes of parthenium

\begin{tabular}{l|c|c|c}
\hline Parameters & Sample sine & Leaf surface & Mean \pm SD \\
\hline & 5 & Lower & $470 \pm 73$ \\
Stomatal freque $n c y($ numberimum & $-3)$ & Upper & $355 \pm 21$ \\
& 5 & Lower & $18.78 \pm 2.61$ \\
Stomatal index $(\%)$ & 5 & Upper & $15.34 \pm 0.67$ \\
Specific leaf area $\left(\mathrm{m}^{2} / \mathrm{kg}\right)$ & 5 & - & $25 \pm 7$ \\
Leaf dry matter content $(\mathrm{mg} / \mathrm{g})$ & 40 & - & $156 \pm 21$ \\
Leaf nitrogen $(\mathrm{mg} / \mathrm{g})$ & 40 & - & $38 \pm 4$ \\
\hline
\end{tabular}

The specific leaf area (SLA, $25 \mathrm{~m}^{2} / \mathrm{kg}$ ) of parthenium weed measured in the present study lies within the range but closer to the lower limit of the value (22.1$41.5 \mathrm{~m}^{2} / \mathrm{kg}$ ) reported by Annapurna and Singh (2003) for the same weed growing under different soil texture conditions. Both these values lies towards the lower half of the expected range $\left(2-80 \mathrm{~m}^{2} / \mathrm{kg}\right)$ and the relatively low SLA is the indicative of resources stress condition (Cornelissen et al. 2003). The leaf dry matter content (LDMC) of parthenium weed was $156 \mathrm{mg} / \mathrm{g}$ (Table 4) which is within the range but closer to the lower limit of values $(50-700 \mathrm{mg} / \mathrm{g}$ ) reported for field grown plants (Cornelissen et al. 2003). Plants with lower LDMC is often associated with freqently disturbed habitats. Mean leaf $\mathrm{N}$ content $(38 \mathrm{mg} / \mathrm{g})$ in the present study site was similar to the value reported by Annapurna and Singh (2003) for parthenium weed grown in soil with relatively high proportion of clay $(35-41 \mathrm{mg} / \mathrm{g})$. The present value is closer to the upper limit of the normal range of leaf nitrogen $(10-50 \mathrm{mg} / \mathrm{g})$ for field grown plants (Cornelissen et al. 2003). High value of leaf nitrogen is often associated with high photosynthetic and relative growth rate. Therefore, a combination of different leaf traits enables the parthenium weed to grow under diverse habitats such as resources poor condition (due to low SLA), disturbed habitats (due to low LDMC) as well as productive sites (due to high leaf nitrogen content).

\section{Pollen viability, achene mass and germination}

Most $(98.8 \%)$ of the pollen grains of parthenium weed were viable. Fruits (achenes) were too small; 100 achenes weighed $0.05 \mathrm{~g}$. Germination of the seeds stored for about eight months under laboratory ambient condition was $82 \%$. This value is relatively low as compared to the germination value $(88 \%$, mean value calculated from the reference) reported by Dubey and Pandey (1988) for six populations of parthenium in India. The relatively low germination in the present study could be the result of long storage period under ambient condition before germination experiment.

\section{Phenology}

The phenological activities of parthenium weed recorded in the field are summarized in Fig. 3. Due to human interferences phenological observation at Kirtipur site could not be completed. The results reported here were from the remaining three sites. Seed germination occured in May when the temperature was increasing and the area received light rainfall (Fig. 1, 3). During early June most of the individual plants were in vegetative stage, but by early July most plants entered into floweing stage (Fig. 3). The plant started flowering and fruiting within 25 to 40 days after germination. In India, this plant starts flowering after four weeks of seedling emergence (Jayachandra 1971). Early flowering with short vegetative phase appears to be the common feature of most of the weeds (Mercado 1979). Anther matured immediately after the involucre of bract of head open. Anther size was approximately $0.2 \mathrm{~mm} \times 1.03-0.05 \mathrm{~mm}$. Anthesis occurred in 2-3 days after bud break. Fruit development occurred after one week of flowering, and seed formation after one week of fruiting. Maximum fruiting and seed formation were observed during August. All the observed plants were in reproductive stage during peak monsoon (July - August). Senescence of the lower leaves of the plant started from late July. Flowering, fruiting and seed formation continued even after the complete senescence of the lower large 
leaves. The plant completed its life cycle in 16-18 weeks with vegetative phase lasting only for four weeks. The duration of flowering and fruiting was long (12-16 weeks from June through September) and continued until the plant finally died in October. This prolonged reproductive phase ennabled the plant to produce a large number of seeds (with half life of about six years in soil, Navie et al. 1998) which is one of the major life history strategies of this weed for high invasiveness (Navie et al. 1996).

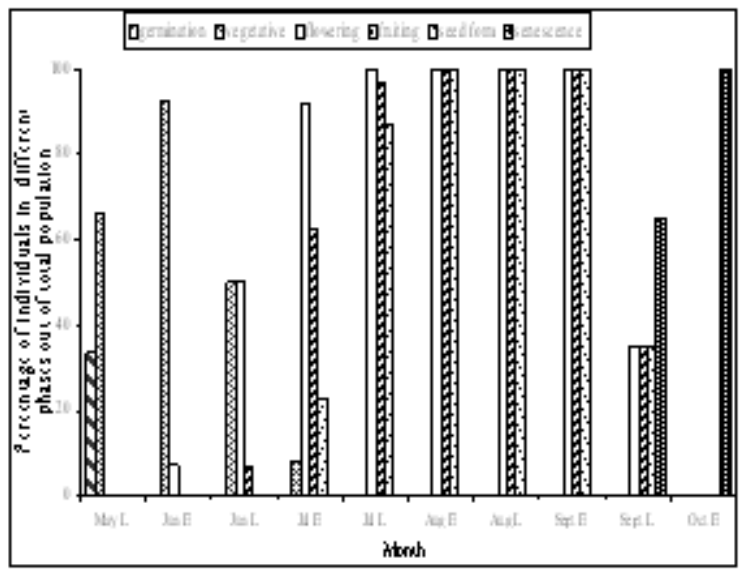

Fig. 3. Summary of phenological activities of Parthenium hysterophorus recorded on tagged individuals at the study sites. Individual at particular phenophase is expressed as the percentage of total population (E: early, L: Late).

One striking feature of the parthenium weed observed during the field survey was that it could germinate, flower and produce seed throughout the year at moist localities. It was found in flowering stage in most months of a year and it could grow even in cold and dry months. This kind of behaviour of this plant has also been reported from Australia (Navie et al. 1996) and India (Mahadevappa 2009).

In conclusion, parthenium weed has been rapidly expanding in the Kathmandy valley and its density has become double in less than a decade. The roadside soil in the valley is highly suitable for the growth and proliferation of the parthenium weed. A combination of different leaf traits enables the this plant to grow under diverse habitats such as resouces poor condition (due to low SLA), disturbed habitats (due to low LDMC) as well as productive sites (due to high leaf nitrogen content). Relatively long reproductive period with high seed output and the capacity to germinate and flower anytime in the year make the parthenium weed a successful invasive weed in the Kathmandu valley.

\section{Acknowledgments}

We acknowledge the help of Khum Bahadur ThapaMagar in preparing a map of the study area, and Sajag Adhikari and Brajesh Shrestha for sampling and laboratory analyses. We also thank the reviewers for their comments and suggestions to improve the manuscript.

\section{References}

Adamson, D. 1996. Determining the economic impact of parthenium on the Australian beef industry: A comparison of static and dynamic approaches. Masters thesis. University of Queensland, Brisbane, Australia.

Annapurna, C. and J.S. Singh. 2003. Variation of Parthenium hysterophorus in response to soil quality: Implications for invasiveness. Weed Research 43:190-196.

Bhatt, D.D. 1977. Natural History and Economic Botany of Nepal. Orient Longman Limited, Calcutta, India.

Chippendale, J.F. and F.D Panetta. 1994. The cost of parthenium weed to the Queensland cattle industry. Plant Protection Quarterly 9:73-76.

Cornelissen, J.H.C., S. Lavorel, E. Garnier, S. Diaz, et al. 2003. A handbook of protocols for standardised and easy measurements of plant funtional traits worldwide. Australian Journal of Botany 51:335-380.

Dhileepan, K. 2009. Managing parthenium weed across diverse landscapes: prospects and limitations. In: Inderjit (ed.) Management of Invasive Weeds. Springer, Pp 227-259.

Dubey, S.K. and H.N. Pandey. 1988. Ray achene polymorphism and germination in ragweed parthenium (Parthenium hysterophorus). Weed Science 36: 566567.

Evans, H.C. 1997. Parthenium hysterophorus: A review of its weed status and the possibilities for biological control. Biocontrol News Information 18:89-98.

Gupta, P.K. 2000. Methods in Environmental Analysis: Water, Soil and Air. Agrobios, Jodhpur, India.

Horneck, D.A. and R.O. Miller. 1998. Determination of total nitrogen in plant tissue. In: Y.P. Kalra (ed.) Handbook of Reference Methods for Plant Analysis. CRC Press. Pp 75-83.

Jayachandra. 1971. Parthenium weed in Mysore state and its control. Current Science 40:568-569.

Karki, D. 2009. Ecological and socioeconomic impact of Parthenium hysterophorus L. invasion in two urban areas in Nepal. MSc thesis. Central Department of Botany, Tribhuvan University, Kathmandu. 
KC, U. 2013. Invasion of Parthenium hysterophorus L. across various land-use types in Kirtipur municipality, Kathmandu, Nepal. MSc thesis. Central Department of Environmental Science, Tribhuvan University, Kathmandu.

Kololgi, P.D., S.D. Kololgi and M.P. Kololgi. 1997. Dermatologic hazards of Parthenium in human beings. In: Proceedings of first international conference on Parthenium management University of Agricultural Science, Dharwad, India. Pp. 18-19.

Mahadevappa, M. 2009. Parthenium: Insight into its menace and management. Studium Press (India) Pvt. Ltd. India.

Meidner, H. and T.A. Mansfield. 1968. Physiology of stomata. McGraw Hill, London.

Mercado, B.I. 1979. Introduction to weed science. SEARCA, Los Banos, Philippines.

Metecalfe, C.R. and L. Chalk. 1965. Anatomy of dicotyledons, Vol. 2. Oxford Claredon Press, UK.

Mishra, K.K. 1990. Parthenium hysterophorus Linn.: A new record for Nepal. Journal of Bombay Natural History Society 88:466-467.

Navie, S.C., F.D. Panette, R.E. McFadyen and S.W. Adkins. 1998. Behaviour of buried and surface-sown seeds of Parthenium hysterophorus. Weed Research 38:335341.

Navie, S.C., R.E. McFadeyan, F.D. Panetta and S.W. Adkins. 1996. The biology of Australian weed 27: Parthenium hysterophorus L. Plant Protection Quaterly 11:76-88.

Nigatu, L., A. Hassen, J. Sharma and S.W. Adkins. 2010. Impact of Parthenium hysterophorus on grazing land communities in north-eastern Ethiopia. Weed Biology and Management 10:143-152.

Pokhrel, K. 2013. Invasiveness of Parthenium hysterophorus: Phenology, population dynamics and response to clipping. MSc thesis. Central Department of Botany, Tribhuvan University, Kathmandu.

Sakya, S.R. 2001. Laboratory manual for cytogenetical study. Central Department of Botany, Tribhuwan University, Kathmandu.

Shrestha, B.B., K.B. Thapa-Magar, A. Poudel and U.B. Shrestha. 2011. Beetle on the battle: Defoliation of Parthenium hysterophorus by Zygogramma bicolorata in Kathmandu valley, Nepal. Botanica Orientalis 8:100-104.

Tamado, T., L. Ohlander and P. Milberg. 2002. Interference by the weed Parthenium hysterophorus L. with grain sorghum: influence of weed density and duration of competition. International Journal of Pest Management 48:183-188.

Timsina, B., B.B. Shrestha, M.B. Rokaya and Z. Munzbergova. 2011. Impact of Parthenium hysterophorus L. invasion on plant species composition and soil properties of grassland communities in Nepal. Flora 206: 233-240.

Tiwari, S., B. Adhikari, M. Siwakoti and K. Subedi. 2005. An Inventory and assessment of invasive alien plant species of Nepal. IUCN - The World Conservation Union, Nepal.

Zobel, D.B., P.K. Jha, N.J. Behan and U.K.R. Yadav. 1987. A practical manual for ecology. Ratna Book Distributors, Kathmandu, Nepal. 